M.V. Petlovanyi, Cand. Sc. (Tech.), orcid.org/0000-0002-8911-4973, V. Yu. Medianyk, Cand. Sc. (Tech.), Assoc. Prof., orcid.org/0000-0001-5403-5338
National Mining University, Dnipro, Ukraine, e-mail: petlyovany@ukr.net

\title{
ASSESSMENT OF COAL MINE WASTE DUMPS DEVELOPMENT PRIORITY
}

Purpose. Assessment of waste dumps development priority for different coal mining areas on the basis of a comprehensive and comparative analysis of their technological, environmental and economic indicators.

Methodology. The paper is based on a comprehensive approach, including analysis of government statistics data on waste accumulation, waste handling sites, the method of expert and integrated assessment, statistical processing methods, photographs of the Google Earth aerospace image program.

Findings. With the help of the expert analysis method, the worth coefficients of each of the nine proposed waste dumps indicators have been established, which enable accurate consideration of their significance in assessing the priority of their development. Integral coefficients characterizing waste dumps are obtained and the order of their gradual involvement into the industrial development is recommended.

Originality. Sphere of integral estimation method application for the new objects - man-made mineral dumps and determining the order of their development - has been expanded. For the first time, the worth coefficients for the complex of technological, economic and environmental indicators were revealed with the expert analysis method for substantiation of the appropriateness of the man-made mineral waste dumps developing priority. For the first time, a priority range of the waste dumps development in the Western Donbas mines has been compiled, which makes it possible to establish rational sequence of putting the dumps in service.

Practical value. The compilation of industrial waste dumps development priority ranges will allow selecting those formations that occupy key positions in the range of their quantitative and qualitative indicators. On the basis of priority series of man-made waste dumps, it becomes possible to create an objective approach to the concept of their industrial development at the state and regional levels.

Keywords: waste dump, coal extraction, expert analysis method, integral estimation method, priority ranges

Introduction. The functioning of the mining industry on the Ukrainian territory leads to an annual accumulation of 0.3 to 0.5 million tons of solid industrial wastes. The bulk falls on the dumps of uncovering and mining open-pit fields formed as a result of minerals extraction [1]. The main waste of underground coal mining is the waste rock from the excavations, which are stored in refuse dumps (terricones) [2,3]. Large-capacity waste formations pollute the environment and occupy valuable agricultural areas [4], and their utilization level is $25-30 \%$, which consists in low-technological using of waste rock and mineral deposits of rock refuse for the construction of dams, roads, equiplanation, and others, which in European practice, as a rule, is not considered as disposal [5]. In the mining of waste rock, the waste of underground mining is also used as a backfilling material when filling out the worked out spaces [6] or processed into fuel due to the high content of combustible components [7].

In developed countries, the man-made accumulated minerals are considered not as wastes, but as an additional source of valuable mineral resources and raw materials for various branches of the economy $[8,9]$. Foreign experience shows that the assessment and development of technogenic deposits in comparison with natural resources is cheaper [10, 11]. A number of investigators demonstrated that the coal mine waste dumps contain a group of rare earth metal content (germanium,

(C) Petlovanyi M.V., Medianyk V.Yu., 2018 scandium, gallium, and others), exceeding the minimum industrial value, as well as coal fractions, alum slate and iron oxides [12, 13]. In turn, the waste rocks can be used as inert aggregate in concrete mixtures, like ballast in road filling, for making ceramic products, an so on [14]. There are also alternative waste dumps resource development technology associated with the creation of energy-based chemical complexes at closing mines to obtain thermal energy, and wide range of exhaust gas products $[15,16]$.

The appropriateness of mining area waste dumps development is determined by the following aspects:

- extraction of coal fractions for additional realization or improvement of mining enterprises' production quality;

- extraction of valuable rare earth metals and aluminic materials;

- the use of rock refuse for construction purposes (road filling, mineral fillers);

- reduction of natural environment pollution;

- reduction of environmental fees for industrial waste;

- creation of new workplaces serving the infrastructure of processing complexes;

- the return of land to public use.

Considering the value of man-made accumulations and actual directions of their use, the industrial development in the near future does not cause any doubts, since retiring natural deposits need an alternative, and the most important issue at the stage of drafting capital 
investment project is the allocation of the most promising and attractive ones for development from the number of man-made mineral objects.

Analysis of the recent research and publications. Recently, the interest of technologists, ore enrichment specialists, ecologists, and chemists to mining and commercial exploitation of technogenic deposits has increased.

In work [17] the analysis of more than 600 mining waste dumps parameters was carried out, which allowed determining the most common forms of dumps, average values of their heights, accumulated rocks and occupied areas. To improve the collection process, processing, analysis and systematization of information on waste dump, it was proposed to conduct electronic certification of the location and determine the prospects of their use for the ecological network formation [18]. It is also known that a ranking rating system is used to rank solid industrial wastes, but only to identify the degree of environmental hazard [19].

However, insufficient attention has been paid to the research areas of dumps development prospect and methodological approaches to them. In mining, there is some experience of assessing the technological feasibility of mining and geological conditions for the deposit development with the help of an integral estimation by the methods of Prof. Malkin. Employees of the design institute "Dniprodiproshaht" used the ranking method to assess the prospects of coal enterprises, which made it possible to create a map of priority mine ranges in different regions and develop programs for the future development of the region and the coal industry [20].

Based on the results of the analysis, it can be stated that the assessment of the waste dumps industrial development priority has not been carried out yet, and the present studies are being carried out for the first time.

Unsolved aspects of the problem. The preliminary assessment of the various man-made formations developing advantages is directly important for planning and updating the development strategy of the country's mineral and raw material complex. In order to provide an adequate estimation, it is required to determine the technical and economic parameters of the accumulated industrial waste. The analysis of scientific research studies has shown that today there is a problem of the manmade wastes development due to the lack of methodological approaches and their application in refuse dump development, which significantly affects the reliable development of project documentation and proper technical-and-economic substantiation on their industrial development advantages.

The task of selecting the most attractive and promising waste dump from the dump tribe is quite complicated, which is explained by the wide variation of the most important qualitative and quantitative parameters of the dumps, for which it is necessary to apply a complex methodical approach based on mathematical research methods.

In addition, while involving waste dump to industrial development there is a problematic issue of determining the importance degree of the main qualitative and quantitative parameters among themselves.
The objective of the work is to estimate the priority of waste dump development on the basis of a comprehensive comparative analysis of their technological, environmental and economic indicators.

To achieve this objective, the following tasks were solved in the work:

- to analyze location and basic qualitative and quantitative parameters of the waste dumps at the Western Donbas coal mines;

- to determine the worth coefficients of the main influencing qualitative and quantitative parameters with the expert analysis;

- to carry comparative analysis of the complex of technological and economic indicators of waste dumps with the integral estimation method;

- to make a priority range of industrial development advantages of waste dumps at the Western Donbas coal mines.

Thus, the priority range establishment of waste dump development is carried out for the first time, and the obtained results can be used for investment projects development.

Selection of the test object. The Dnipropetrovsk region takes the leading place in the coal mining of Ukraine. So, coal mining in the region amounted to 20.192 million tons or $57.7 \%$ of all production in the country for 2017 [21]. Gas flammable coal is produced by PJSC DTEK Pavlohradvuhillia, where there are 5 colliery groups, each of which includes 2 mines, respectively, and the volume of incoming contaminants to the dumps is the largest among all coal enterprises and associations in Ukraine.

A register analysis, which is in the public domain, of waste handling sites (WHSs) of the Dnipropetrovsk region made it possible to establish that during the Western Donbas coal seams industrial development 11 rock dumps have been formed, in which more than 100 million tons of contaminants with a total area of more than 200 hectares were accumulated; they are dumps of "Pershotravneva" closed mine, 2 dumps of "Yuvileina" mine, 2 dumps of "Stepova" mine, the dump of "M.I.Stashkova" mine, the dump of "Dniprovska" mine, the dump of "Samarska" mine, 2 dumps of "Ternivska" mine, the dump of "Zakhidno-Donbaska" mine. The coal content in the formed dumps of the Western Donbas mines reaches $12.0 \%$, the shape of all is flat. The waste dumps gradation of PJSC DTEK Pavlohradvuhillia by rock accumulation volume and occupied area is presented in Fig. 1.

The analysis of Fig. 1 allows us to state that the mines with greater capacity formed significant volumes of contaminants 15.0-17.0 million tons, while the areas under them reach 20-35 hectares. One of the largest dumps for the occupied area belongs to "M.I. Stashkova" mine (Fig. 1). It should be noted that 5-7 times as much land suitable for agriculture is allocated for flat dumps compared to cone-shaped dumps. Therefore, from the position of environmental protection, the first-priority utilization of flat dumps is obvious. Using the Google Earth program, aerial photographs of some waste dumps in the Western Donbas coal mines (Fig. 2) were obtained 


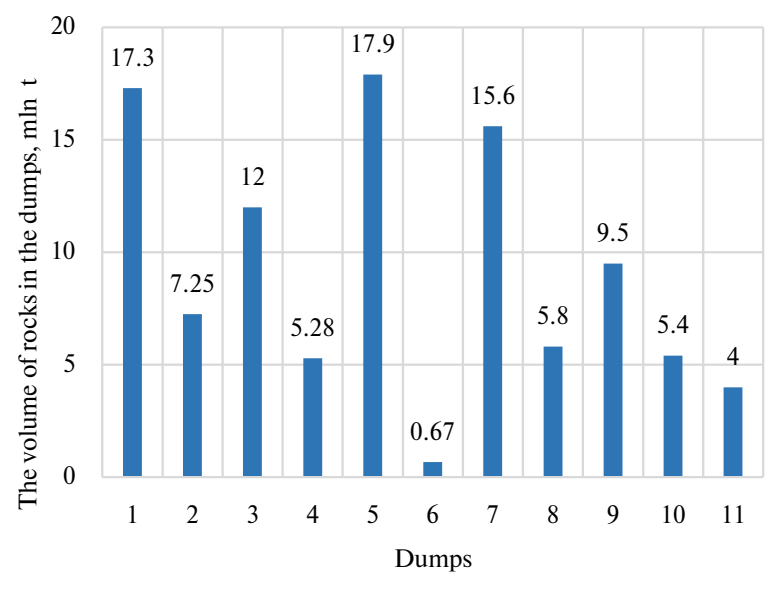

$a$

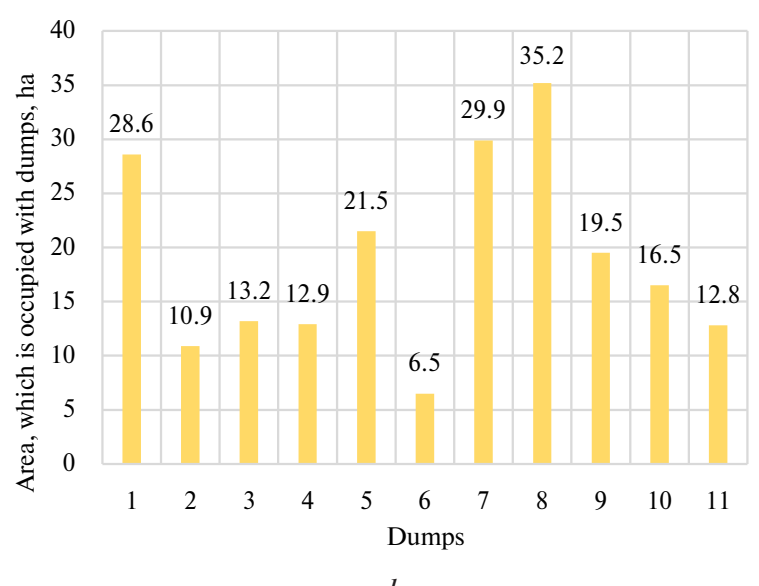

b

Fig. 1. Gradation of dumps by volume of stored rocks (a) and occupied area $(b)$ :

1 -dump No. 1 of "Yuvileina" mine; 2 - dump No. 2 of "Yuvileina" mine; 3 - dump No.1 of "Ternivska" mine; 4-dump No. 2 of "Ternivska" mine; 5-dump No. 1 (block No. 1) "Stepova" mine; 6-dump No. 2(block No. 2) "Stepova" mine; 7-dump (block No. 1) of "Zakhidno-Donbaska" mine; 8-dump of "M.I. Stashkova" mine; 9-dump of "Dniprovska" mine; 10 - dump of "Samarska" mine; 11 - dump of "Pershotravneva" closed mine and distances to the nearest settlements with a developed infrastructure were determined.

In the present work, it is planned to rank waste dumps in the Western Donbas mines to build their rating estimates and identify the most promising to the prior industrial development, which will allow replacing the natural deposits with man-made ones in the future.

Methods of research. To solve the scientific problem of determining the waste dumps industrial development priority, a comprehensive methodological approach was adopted in the work, including analysis of the accumulation and selection of the main indicators to compare rock dumps of the Western Donbas mines; determination of the worth coefficients of waste dumps parameters using the expert analysis; determination of integral estimation coefficient using methods of mathematical statistics.

Based on the results of the analysis of available information data on waste dumps in the Western Donbas mines in order to assess the priority of their development, it is proposed to use the following parameters of waste dumps in the complex-comparative analysis:

1. The volume of stock rocks. The indicator that characterizes the value of stocks of valuable resources. Priority is given to the greatest value.

2. Coal content. The main indicator that determines the profitability of the dumps development. Priority is given to the greatest value.

3. Occupied area. From the position of environmental protection, to clear valuable lands as soon as possible is necessary. Priority is given to the greatest value.

4. Availability of supply lines. An important aspect in the creation of processing complexes and the functioning of equipment and mechanisms. Priority is given to the availability of supply lines.

5. Availability of transport junctions. Indicator, which affects the technological access to the waste dump. Priority is given to the transport junction.

6 . The form of the dump. From a technological point of view, a dump with a smaller indicator of its height and a larger occupied area is the most convenient for development. In calculation, the shape of the dump is taken into account by the ratio of the parameters $H / S$ (where

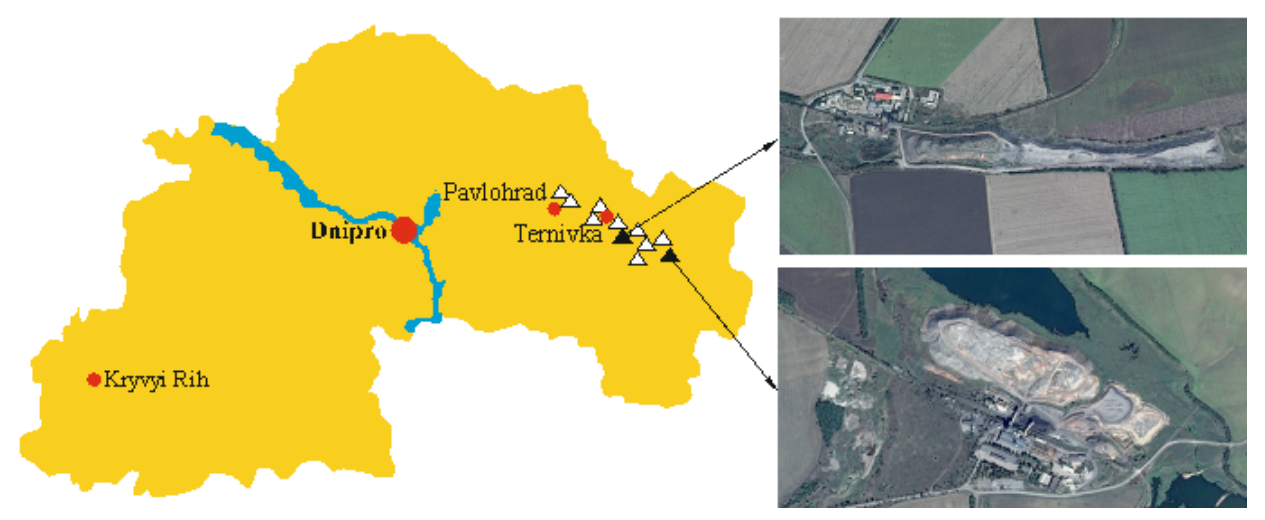

Fig. 2. Spatial location of major coal waste dumps in Dnipropetrovsk region: right top corner - "M.I. Stashkova”; right low corner - "Yuvileina” dump No. 1 
$H$ is the dump height, $\mathrm{m} ; S$ is the area occupied by the dump, $\mathrm{m}^{2}$ ). Priority is given to the lowest value of the dump.

7. Rock moisture. The index, which reduces the rock strength properties and worsens the conditions of rock mass delivery. Priority is given to the smallest value.

8. Sulfur content. It leads to a decrease in coal quality and pollution of the atmosphere when it is burned. Priority is given to the smallest value.

9. Proximity to population areas. The indicator that influences the costs of valuable resource, extracted from the waste dumps, transporting. Priority is given to the smallest value.

The actual data of one of waste dumps are given in Table 1.

The proposed qualitative and quantitative indicators of 10 dumps from 11 existing ones are the initial data for the peer review to determine the degree of their importance and establish integral estimation coefficients, on the basis of which it is possible to form a priority range of waste dumps industrial development in the Western Donbas and to identify the possible priority of putting facilities into operation.

For the peer review, the questionnaire method was selected, the essence of which is to select scientists who conduct research in the field of man-made waste development problems in terms of technology, enrichment, ecology, as well as economic analysis and have corresponding scientific works and regarded in scientific circles. In the expert assessment, 4 Doctors of Technical Sciences and 7 Candidates of Technical Sciences from various research fields took part in the expert assessment.

The experts participated in the questionnaire survey, in which it was necessary to assess the degree of significance of waste dump indicators according to the scale of 0 to 10 (the higher the score, the importance of the indicator is considered to be more significant).

Then, the average value of the importance of each indicator is calculated. The degree of consistency of opinions of experts was evaluated by the concordance coefficient determined by known mathematical transformations and varying from 0 to 1 .

Determination of the integral estimation coefficients of waste dumps was carried out using mathematical statistics methods. The sequence of coefficients according to the methods of Prof. Malkin is as follows:

- a summary table of the initial data is prepared, indicating the benchmarkable (best) indicator;

- deviations of dump indicators values are calculated;

- deviation matrix of dump indicators is formed;
- integral coefficients of dumps are calculated directly, the minimum value of which indicates the industrial development priority.

Results of the research. To determine the priority of dumps industrial development with the peer review method according to the proposed methodology, the degree of qualitative and quantitative index importance was established. From the results of the peer review, it follows that the experts identified the following indicators as the most significant ones in assessing the priority of the dumps development: coal content, the volume of stock rocks, proximity to the population areas, and so forth in descending order.

As a result of the processing of the expert evaluation data, the experts identify the following indicators as the most significant indicators in assessing the priority of the development of rock dumps: the volume of stockpiled rocks, the coal content, the proximity to the populated area, the occupied area, the availability of traffic interchanges, i.e. in descending order, which is shown in the histogram (Fig. 3). The coefficient of concordance for 9 analyzed indicators by 11 experts was $w=0.54$, which indicates the average degree of consistency of experts' opinions. This indicates the specifics and novelty of the issue under consideration, since research on the priority of development is being carried out for the first time, and in serious industrial scales the experience in the development of rock dumps has never been mastered. We consider the average degree of consistency to be appropriate for the solution of the problem of the development of rock dumps, since the method of expert evaluation allows us to identify the key positions occupied by rock dumps by certain indicators.

To increase the degree of consistency in resolving such issues, it is recommended to increase the number of experts.

Next, the integral coefficients of 10 rock dumps were calculated and the priority series of expediency of development according to their indicators was compiled in the following sequence:

1. Determining relative deviations of waste dumps indicators

$$
\delta_{i, j}=\frac{\left|I_{i j}^{b}-I_{i j}^{a}\right|}{I_{i}^{\max }+I_{i}^{\min }},
$$

where $I_{i j}^{b}$ is benchmarkable (best) indicator of all rock dumps; $I_{i j}^{a}$ is the actual data of waste dump index; $I_{i}^{\max }$ is the highest value of the indicator from all waste dumps; $I_{i}^{\mathrm{min}}$ is the lowest value of the indicator from all

Table 1

Technological, economic and environmental indicators of one waste dump of the Western Donbas mines

\begin{tabular}{|c|c|c|c|c|c|c|c|c|c|c|}
\hline Mine & $\begin{array}{c}\text { No. } \\
\text { of the dump }\end{array}$ & $\begin{array}{l}\text { Volume of } \\
\text { rocks, mln } \mathrm{t}\end{array}$ & $\begin{array}{c}\text { Coal } \\
\text { content, } \\
\%\end{array}$ & $\begin{array}{c}\text { Area, } \\
\text { ha }\end{array}$ & $\begin{array}{l}\text { Shape of } \\
\text { the dump }\end{array}$ & $\begin{array}{l}\text { Transport } \\
\text { junctions }\end{array}$ & $\begin{array}{c}\text { Supply } \\
\text { lines }\end{array}$ & $\begin{array}{c}\text { Rock } \\
\text { moisture, } \\
\%\end{array}$ & $\begin{array}{c}\text { Sulfur } \\
\text { content, } \\
\%\end{array}$ & 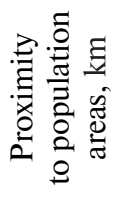 \\
\hline Stepova & No.1 & 17.9 & 10.1 & 21.5 & 3.53 & + & - & 5.0 & 1.20 & 2.2 \\
\hline
\end{tabular}




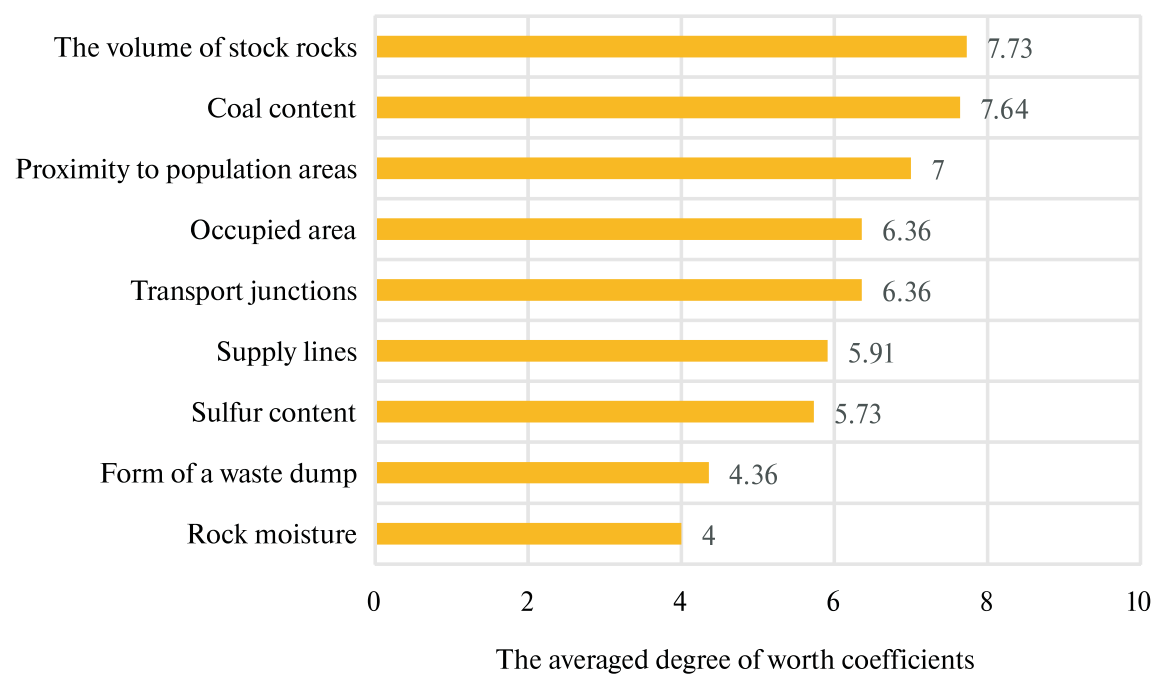

Fig. 3. Peer review results according to the waste dumps indices significance

waste dumps; indices $i$ and $j$ are the number of the indicator and the number of the waste dump respectively.

2. Drawing up a deviation matrix of the waste dumps parameters (Table 2).

3. Identifying the integral indicators of the waste dumps developing priority

$$
k_{3 n t}=\frac{1}{\varphi_{a v}} \cdot \sqrt{\sum_{i=1}^{i=m}\left(\delta_{i j} \cdot \varphi_{i j}\right)^{2}} \rightarrow 0,
$$

where $k_{\text {int }}$ is the total integral index of the rock dump; $\varphi_{a v}$ is the average value of the degree of importance of the parameters of the rock dump.

The integral indicator of the dump with the lowest value shows the advantages of its primary development. The smaller the value of the coefficient is, the higher the priority place that the waste dump occupies is.

As a result of the calculations for 10 waste dumps, a priority range of the waste dumps development at the Western Donbas mines was formed for the first time (Fig. 4).
The analysis of the dump development priority range (Fig. 4) shows that the promising dump for immediate development is "Zakhidno-Donbaska" mine with a minimum integral index of 0.56 , which is associated with a high coal content, the lowest sulfur content, the presence of all supply lines, convenient geometric parameters of the dump, a considerable occupied area, requiring a quick cleaning up and a significant volume of stocked rocks.

The least promising in the range is dump No. 2 "Stepova" mine, which, accordingly, is characterized by less attractive parameters: a rather small amount of accumulated rocks, insignificant occupying area, and considerable distance from the population areas. According to the priority range, four promising dumps for development should be identified, whose integral indicators vary in an insignificant range of $0.56-0.78$ and, in essence, the comparable indicators are close to one another - dump of "Zakhidno-Donbaska" mine, dump No. 1 of "Ternivska" mine, dump No. 1 of "Yuvileina" mine, dump No. 1 "Stepova" mine.

Table 2

Deviation matrix of dump indicators

\begin{tabular}{|c|c|c|c|c|c|c|c|c|c|c|c|}
\hline Indicator & 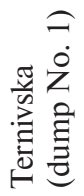 & 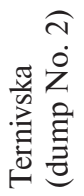 & 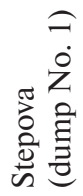 & 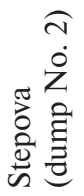 & 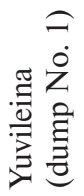 & 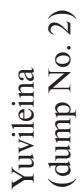 & 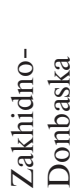 & 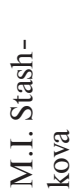 & 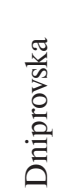 & 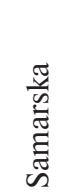 & 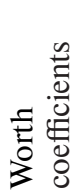 \\
\hline The volume of stock rocks & 0.32 & 0.68 & 0.00 & 0.93 & 0.03 & 0.57 & 0.12 & 0.65 & 0.45 & 0.68 & 7.73 \\
\hline Coal content & 0.07 & 0.00 & 0.12 & 0.04 & 0.00 & 0.62 & 0.12 & 0.13 & 0.05 & 0.14 & 7.64 \\
\hline Occupied area & 0.41 & 0.53 & 0.33 & 0.69 & 0.16 & 0.58 & 0.13 & 0.00 & 0.38 & 0.45 & 6.36 \\
\hline Shape of the dump & 0.00 & 0.06 & 0.49 & 0.03 & 0.17 & 0.56 & 0.18 & 0.09 & 0.20 & 0.00 & 4.36 \\
\hline Transport junctions & 0.00 & 0.00 & 0.00 & 0.00 & 0.00 & 0.00 & 0.00 & 0.00 & 0.00 & 0.00 & 6.36 \\
\hline Supply lines & 0.00 & 0.00 & 0.50 & 0.50 & 0.50 & 0.50 & 0.50 & 0.50 & 0.50 & 0.50 & 5.91 \\
\hline Rock moisture & 0.32 & 0.45 & 0.03 & 0.03 & 0.39 & 0.27 & 0.09 & 0.00 & 0.03 & 0.32 & 4.36 \\
\hline Sulfur content & 0.36 & 0.67 & 0.36 & 0.25 & 0.41 & 0.28 & 0.00 & 0.27 & 0.10 & 0.46 & 5.73 \\
\hline Proximity to population areas & 0.00 & 0.00 & 0.13 & 0.38 & 0.05 & 0.05 & 0.00 & 0.86 & 0.83 & 0.30 & 7.00 \\
\hline
\end{tabular}




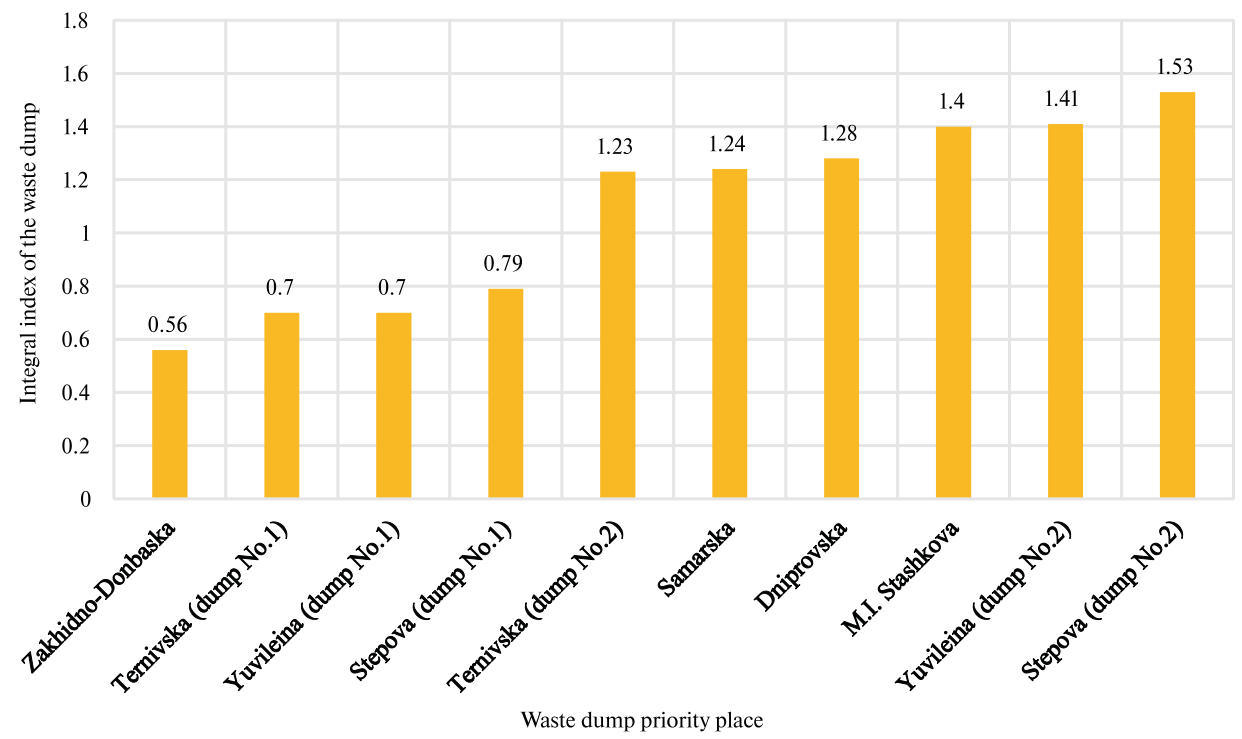

Fig. 4. Priority range of waste dump development at the Western Donbas coal mines

Priority ranges allow revealing man-made mineral formations from a significant number of objects occupying key positions on their quantitative and qualitative indicators complex. Based on the construction of priority series of development of man-made waste, it becomes possible to create an objective approach to the concept of their industrial development and planning the strategy for the development of the mineral raw material stock of technogenic raw materials.

Priority ranges formation has an advisory and informative nature of the waste dumps representation by their development prioritizing. Data on the valuable rare earth elements content in mining waste dumps will strengthen the priority of their development significantly. Extending topographic, geodetic, geographic, economic, social, and other data could increase the reliability of man-made formations development order. With the increase in the complex of indicators, the accuracy of rating assessments of man-made waste formations according to the priority of their development increases.

Such a methodological approach for determining the development priority can be extended to tailing, sludge, ash and slag waste dumps, smelter slag dumps and other types of man-made accumulations, provided that there is an appropriate information base for their characteristics.

Conclusions.

1. Register analysis of the Dnipropetrovsk region's Pressure Transient Test made it possible to establish that during the industrial development of the Western Donbas coal seams, 11 waste dumps have been formed, in which more than 100 million tons of contaminants with a total area of more than 200 hectares have been accumulated possessing the resource potential. Dumps contain such valuable resources as a group of high content rare-earth elements, coal fractions alumina and contaminants that can be used for road and civil construction.

2. An expert analysis on importance of a complex of the technological, economic and environmental indica- tors of waste dumps has been carried out. As a result of the processing of the expert evaluation data, it was established that the most significant indicators for the development of rock dumps are the volume of stored rocks, the coal content, proximity to the settlement, and so forth. The concordance coefficient was $w=0.54$, which indicates the average degree of agreement among experts. This also indicates the specificity and novelty of the issue under consideration, since for the first time an assessment of the priority of rock dumps of coal mines has been given, and on an industrial scale the experience of their development has not been mastered.

3 . The coefficients of the integral estimation are established and the priority range for waste dumps development was constructed for the first time, showing that the promising dump for immediate development is "Zakhidno-Donbaska" mine with a minimum integral index of 0.56 , and the least promising is dump No. 2 "Stepova" mine (the largest integral index - 1.53). According to the priority range, four dumps promising for development should be identified, whose integral indicators vary in an insignificant range of $0.56-0.79$ and, in essence, the comparable indicators are close to one another - dump of "Zakhidno-Donbaska" mine, dump No. 1 of "Ternivska" mine, dump No. 1 of "Yuvileina" mine, dump No.1 of "Stepova" mine. The construction of priority series is recommendatory and illustrative for investment attractiveness of projects for the development of man-made waste.

4. Priority ranges allow revealing man-made accumulations from a significant number of objects occupying key positions in the complex of their quantitative and qualitative indicators. On the basis of man-made mineral formations priority ranges, a more objective approach to the concept of their industrial development and planning a strategy for the development of the mineral raw material fund of Ukraine's technogenic raw materials is possible.

The construction of priority series for the development of man-made wastes is of great practical importance 
for planning a strategy for the development of the mineral raw material stock of technogenic raw materials accumulated as a result of industrial activities of enterprises. The proposed methodical approach to prioritizing the development of rock dumps of coal mines can be extended to other types of man-made wastes from the fuel and energy as well as mining and metallurgical complexes.

Acknowledgements. The work was carried out within the framework of scientific projects with the support of the Ministry of Education and Science of Ukraine No.0116U008041 and No.0117U001127.

\section{References.}

1. Pinder, V. F. and Popovych, V. V., 2017. Reclamation of mine rock dumps of liquidates mines in Lviv-Volyn coal basin. Scientific Bulletin of UNFU, 27(3), pp. 113116. DOI:10.15421/40270325.

2. Ciesielczuk, J., Misz-Kennan, M., Hower, J.C. and Fabiańska, M. J., 2014. Mineralogy and geochemistry of coal wastes from the Starzykowiec coal-waste dump (Upper Silesia, Poland). International Journal of Coal Geology, 127,pp.42-55. DOI:10.1016/j.coal.2014.02.007. 3. Petlovanyi, M. V., Lozynskyi, V.H., Saik, P. B. and Sai, K.S., 2018. Modern experience of low-coal seams underground mining in Ukraine. International Journal of Mining Science and Technology. Article in press. DOI: 10.1016/j.ijmst.2018.05.014.

4. Khomenko, O., Kononenko, M., Myronova, I. and Sudakov, A., 2018. Increasing ecological safety during underground mining of iron-ore deposits. Naukovyi Visnyk Natsionalnoho Hirnychoho Universytetu, 2, pp. 2938. DOI: 10.29202/nvngu/2018-2/3.

5. Filonenko, O., 2018. Sustainable development of Ukrainian iron and steel industry enterprises in regards to the bulk manufacturing waste recycling efficiency improvement. Mining of Mineral Deposits, 12(1), pp. 115122. DOI: $10.15407 / \operatorname{mining} 12.01 .115$.

6. Kuz'menko, O., Petlyovanyy, M. and Stupnik, M., 2013. The influence of fine particles of binding materials on the strength properties of hardening backfill. Annual Scientific-Technical Collection Mining of Mineral Deposits, pp. 45-48. DOI: 10.1201/b16354-10.

7. Gayday, O., 2013. Research studies on structural-mechanical properties of coal tailings as disperse systems. Annual Scientific-Technical Collection Mining of Mineral Deposits, pp. 327-331. DOI: 10.1201/b16354-61.

8. Koizhanova, A., Osipovskaya, L. and Erdenova, M., 2012. Study of precious metals extraction recovery from technogenic wastes. In: $12^{\text {th }}$ International Multidisciplinary Scientific GeoConference and EXPO - Modern Management of Mine Producing, Geology and Environmental Protection, SGEM 2012 [online], 1, pp. 843-846. DOI: $10.5593 /$ sgem2012/s03.v1059.

9. Kolesnikov, V.A., Il'in, V. I., Brodskiy, V. A. and Kolesnikov, A. V., 2017. Electroflotation during wastewater treatment and extraction of valuable compounds from liquid technogenic waste: A review. Theoretical Foundations of Chemical Engineering, 51(4), pp. 369-383. DOI: 10.1134/s0040579517040200.

10. Strizhenok, A. and Tcvetkov, P., 2017. Ecology-economical assessment of new reclamation method for cur- rently working technogenic massifs. Journal of Ecological Engineering, 18(1), pp. 58-64. DOI: 10.12911/ 22998993/66251.

11. Taskin, A. V., Alekseiko, L. N. and Slesarenko, V. V., 2016. Geo-economical assessment of the prospects for processing ash and slag waste of coal-fired power plants of the Far Eastern Region of Russia. International Journal of Oceans and Oceanography, 10(2), pp. 219-234.

12. Cherkasova, T.G., Cherkasova, E.V., Tatarinova, E.S., Bobrovnikova, A.A., Goryunova, I. P., Mihaylenko, Y. A. and Isakova, I. V., 2014. Rare earth elements in Kuznetsk Coals: Ability to excavate and new functional materials. Proceedings of the Taishan Academic Forum - Project on Mine Disaster Prevention and Control. pp. 418-420. DOI: 10.2991/mining-14.2014.61.

13. Zubova, L. G., Zubova, A.R., Verekh-Belousova, K. I. and Oleynik, N. V., 2012. Obtaining metals from the waste pits of the Donbass coal mines. Luhansk: VNU im. V. Dalia [online]. Available at: <www.geokniga.org/ bookfiles/geokniga-monografiya-no-2-ot-17-06-2012. doc 12.06.2018> [Accessed 25 September 2017].

14. Shreekant, R. L., Aruna, M. and Vardhan, H., 2016. Utilisation of mine waste in the construction industry a critical review. International Journal of Earth Sciences and Engineering, 09(01), pp. 182-195.

15. Falshtynskyi, V.S., Dychkovskyi, R. O., Saik, P. B., Lozynskyi, V. H. and Cabana, E. C., 2017. Formation of thermal fields by the energy-chemical complex of coal gasification. Naukovyi Visnyk Natsionalnoho Hirnychoho Universytetu, 5, pp. 36-42.

16. Bondarenko, V., Svietkina, O. and Sai, K., 2017. Study of the formation mechanism of gas hydrates of methane in the presence of surface-active substances. Eastern-European Journal of Enterprise Technologies, 5(6(89)), pp. 48-55. DOI: 10.15587/1729-4061.2017.112313.

17. Bondarenko, V.I., Vivcharenko, A.V. and Yarkovych, A. I., 2013. New technique of coal mining very thin seams with leaving rock in mine. Szkola Eksplotacji Podziemnej, pp. 75-81.

18. Pavlychenko, A.V., Fedotov, V.V., Buchavy, Yu. V. and Kovalenko, A. A., 2014. Development of electronic environmental passport of coal mine waste-rock piles. Naukovyi Visnyk Natsionalnoho Hirnychoho Universytetu, 3, pp. 105-110.

19. Datta, M., Kumar, A. and Bhowmik, R., 2017. Rehabilitation and expansion of operational municipal solid waste (MSW) dumps of India. Geoenvironmental Practices and Sustainability, pp. 57-67. DOI: 10.1007/ 978-981-10-4077-1_7.

20. Pinkovskyi, G. S., 2013. Organization and technology of designing mines. Dnipro: National Mining University. 21. Coal mining in Ukraine in 2017, 2017. Energy of Ukraine (UA Energy) [online], Available at: <http:// uaenergy.com.ua/post/30399/dobycha-uglya-vukraine-v-2017-g-snizilas-na/> [Accessed 5 December 2017].

\section{Оцінка пріоритетності розробки породних відвалів вугільних шахт}

М. В. Петльований, В. Ю. Медяник 
Державний вищий навчальний заклад „Національний гірничий університет“, м. Дніпро, Україна, e-mail: petlyovany@ukr.net

Мета. Оцінка пріоритетності розробки породних відвалів вугільних шахт різних гірничопромислових регіонів на підставі комплексно-порівняльного аналізу їх технологічних, екологічних і економічних показників.

Методика. У роботі використано комплексний підхід, що включає аналіз даних державної статистики з накопичення відходів, місць видалення відходів, метод експертної та інтегральної оцінки, методи статистичної обробки, фотознімки програми аерокосмічних зображень Google Earth.

Результати. За допомогою методу експертної оцінки встановлені коефіцієнти важливості кожного з дев'яти запропонованих показників породних відвалів, що дають можливість точного обліку їх значимості в оцінці першочерговості їх розробки. Отримані інтегральні коефіцієнти, що характеризують породні відвали й рекомендована черговість їх поступового залучення у промислову розробку.

Наукова новизна. Розширена область застосування методу інтегральної оцінки для нових об'єктів - техногенних відходів і визначення черговості їх розробки. Уперше виявлені коефіцієнти важливості комплексу технологічних, економічних і екологічних показників породних відвалів методом експертної оцінки для обгрунтування доцільності першочерговості розробки техногенних відходів. Уперше складено пріоритетний ряд першочергової розробки породних відвалів шахт Західного Донбасу, що дозволяє встановити раціональну послідовність уведення відвалів в експлуатацію.

Практична значимість. Складання пріоритетних рядів промислового освоєння породних відвалів дозволяє вибирати ті, що займають ключові позиції за комплексом їх кількісно-якісних показників. На основі пріоритетних рядів техногенних відходів з'являється можливість створення об'єктивного підходу до концепції їх промислового освоєння на державному й регіональному рівні.

Ключові слова: породний відвал, вуглевидобуток, метод експертної оцінки, метод інтегральної оцінки, пріоритетний ряд

\section{Оценка приоритетности разработки породных отвалов угольных шахт}

М. В. Петлёваный, В. Ю. Медяник
Государственное высшее учебное заведение „Национальный горный университет“, г. Днепр, Украина, e-mail: petlyovany@ukr.net

Цель. Оценка приоритетности разработки породных отвалов угольных шахт различных горнопромышленных регионов на основании комплексно-сравнительного анализа их технологических, экологических и экономических показателей.

Методика. В работе использован комплексный подход, включающий анализ данных государственной статистики по накоплению отходов, мест удаления отходов, метод экспертной и интегральной оценки, методы статистической обработки, фотоснимки программы аэрокосмических изображений Google Earth.

Результаты. С помощью метода экспертной оценки установлены коэффициенты важности каждого из девяти предложенных показателей породных отвалов, которые дают возможность точного учета их значимости в оценке первоочередности их разработки. Получены интегральные коэффициенты, характеризующие породные отвалы и рекомендована очередность их постепенного вовлечения в промышленную разработку.

Научная новизна. Расширена область применения метода интегральной оценки для новых объектов - техногенных отходов и определения очередности их разработки. Впервые выявлены коэффициенты важности комплекса технологических, экономических и экологических показателей породных отвалов методом экспертной оценки для обоснования целесообразности первоочередности разработки техногенных отходов. Впервые составлен приоритетный ряд первоочередной разработки породных отвалов шахт Западного Донбасса, позволяющий установить рациональную последовательность ввода отвалов в эксплуатацию.

Практическая значимость. Составление приоритетных рядов промышленного освоения породных отвалов позволяет выбирать те, которые занимают ключевые позиции по комплексу их количественно-качественных показателей. На основе приоритетных рядов техногенных отходов появляется возможность создания объективного подхода к концепции их промышленного освоения на государственном и региональном уровне.

Ключевые слова: породный отвал, угледобыча, метод экспертной оценки, метод интегральной оцен$\kappa и$, приоритетный ряд

Рекомендовано до публікації докт. техн. наук В. І. Голіньком. Дата надходжсення рукопису 21.05.17. 